\title{
Basin-wide estimates of the input of methane from seeps and clathrates to the Black Sea
}

\author{
J.D. Kessler ${ }^{\text {a,*, W.S. Reeburgh }}{ }^{\text {a }}$, J. Southon ${ }^{a}$, R. Seifert ${ }^{b}$, \\ W. Michaelis ${ }^{b}$, S.C. Tyler ${ }^{a}$ \\ ${ }^{a}$ Department of Earth System Science, University of California Irvine, Irvine, CA, 92697-3100 USA \\ b Institute for Biogeochemistry and Marine Chemistry, University of Hamburg, Bundesstrasse 55, 20146, Hamburg, Germany
}

Received 12 July 2005; received in revised form 13 December 2005; accepted 6 January 2006 Available online 17 February 2006

Editor: H. Elderfield

\begin{abstract}
Numerous methane-emitting bottom features, such as seeps, methane clathrate hydrates (clathrates), and mud volcanoes, have been identified recently in the Black Sea. The fluxes of methane from these sources averaged over large spatial scales are unknown. Here we take advantage of the fact that the Black Sea is a semi-enclosed basin with restricted deep water circulation to establish firstorder estimates of basin-wide fluxes of methane from these sources to the water column and atmosphere. First, we measured the natural radiocarbon content of methane $\left({ }^{14} \mathrm{C}-\mathrm{CH}_{4}\right)$ dissolved in the water column and emitted from seeps. The ${ }^{14} \mathrm{C}-\mathrm{CH}_{4}$ results showed that the dominant source of methane to the water column is emitted from seeps and a smaller source is diagenetically produced in relatively modern sediments. The ${ }^{14} \mathrm{C}-\mathrm{CH}_{4}$ results were then used to partition a basin-wide total methane budget; this analysis estimated the basin-wide flux of methane from seeps and clathrates to the water column to be 3.60 to $4.28 \mathrm{Tg} \mathrm{yr}^{-1}$. Second, a geochemical box model was used to calculate possible distributions of methane inputs from seeps and clathrates as well as provide additional estimates of the basin-wide flux of methane from seeps and clathrates to the water column (4.95 to $\left.5.65 \mathrm{Tg} \mathrm{yr}^{-1}\right)$.
\end{abstract}

(C) 2006 Elsevier B.V. All rights reserved.

Keywords: methane; seeps; methane clathrate hydrates; Black Sea; methane radiocarbon; seep methane flux

\section{Introduction}

As the world's largest anoxic basin, the Black Sea has been the site of numerous studies on methane $\left(\mathrm{CH}_{4}\right)$ biogeochemistry (e.g. [1-14]). Concentration and oxidation rate measurements of $\mathrm{CH}_{4}$ dissolved in the water column and sediments [1-6] have been used to assemble $\mathrm{CH}_{4}$ geochemical budgets for the entire Black Sea [1] and

\footnotetext{
* Corresponding author. Present address: Department of Geosciences, Guyot Hall, Princeton University, Princeton, NJ, 085441003, USA. Tel.: +1 609258 6899; fax: +1 6092581274 .

E-mail address: jdkessle@princeton.edu (J.D. Kessler).
}

the north-western shelf [5]. These studies indicate that the Black Sea is the largest surface water reservoir of dissolved $\mathrm{CH}_{4}(96 \mathrm{Tg})$ of which $0.066 \mathrm{Tg} \mathrm{yr}^{-1}$ are emitted into the atmosphere [1].

During the last decade, numerous seeps and mud volcanoes, emitting or capable of emitting $\mathrm{CH}_{4}$, have been identified on the shelf and slope of the northern Black Sea [7-11]. Methane clathrate hydrates (clathrates), an important global $\mathrm{CH}_{4}$ reservoir estimated to contain over $10^{3}$ times more $\mathrm{CH}_{4}$ than the atmosphere [15], are also present in deep Black Sea sediments [11,12], and represent an unknown $\mathrm{CH}_{4}$ source. The stability of clathrates is governed by pressure, temperature, and $\mathrm{CH}_{4}$ concentration 
[16-19]. Even in a pressure-temperature zone where clathrates are stable, a clathrate will decompose if the water surrounding it contains a $\mathrm{CH}_{4}$ concentration below what is necessary to form clathrates. This condition is not met for clathrates outcropping at the seafloor and in some sediments. While a few direct observations of individual seeps have led to a regional estimate of fluxes of $\mathrm{CH}_{4}$ from seeps to the atmosphere [7], there are no estimates of the quantity of $\mathrm{CH}_{4}$ contributed to the entire Black Sea by these sources. Recent discoveries of globally distributed seeps suggest that $\mathrm{CH}_{4}$ released from seeps and clathrates may play a role in the global and oceanic $\mathrm{CH}_{4}$ budget $[10,20,21]$ and climate change [22-24]. One of the limitations to understanding the role of these reservoirs in global carbon cycles and climate change is that there have been few attempts to extend individual observations to larger spatial scales.

Here we present first-order estimates for basin-wide fluxes of $\mathrm{CH}_{4}$ from seeps and clathrates to the water column and atmosphere in the Black Sea. To estimate these basin-wide fluxes, we conducted both measurement and modeling studies, which give similar results. The measurement studies involved two main investigations. First, the total source of $\mathrm{CH}_{4}$ into the waters of the Black Sea was determined. If the concentration of $\mathrm{CH}_{4}$ in the waters of the Black Sea is in steady-state, then the total source of $\mathrm{CH}_{4}$ to water column is balanced by the total sink of $\mathrm{CH}_{4}$ from the water column. Reeburgh et al. [1] quantified the magnitudes of the sinks of $\mathrm{CH}_{4}$ from the waters of the Black Sea (Table 2) and we present $\delta^{13} \mathrm{C}-\mathrm{CH}_{4}$ data that suggests that the $\mathrm{CH}_{4}$ concentration is in steady-state. Second, the total source of $\mathrm{CH}_{4}$ into the waters of the Black Sea was partitioned between a) $\mathrm{CH}_{4}$ that is released from seeps and decomposing clathrates and b) $\mathrm{CH}_{4}$ that is produced diagenetically in relatively modern sediments and released to the water column. We measured the natural radiocarbon content of $\mathrm{CH}_{4}\left({ }^{14} \mathrm{C}-\right.$ $\mathrm{CH}_{4}$ ) in the Black Sea (Fig. 1, Table 1) and performed a ${ }^{14} \mathrm{C}-\mathrm{CH}_{4}$ isotope mass balance to determine the fraction of $\mathrm{CH}_{4}$ emitted to the water column that is from seeps and decomposing clathrates. (Previous ${ }^{14} \mathrm{C}-\mathrm{CH}_{4}$ measurements from seeps and clathrates show that they are both devoid of natural radiocarbon [25-27], so radiocarbon measurements cannot distinguish between $\mathrm{CH}_{4}$ released from seeps and clathrates; for brevity, we use the term "seep" to apply to both.) This fraction was multiplied by the total source of $\mathrm{CH}_{4}$ to the Black Sea, resulting in an estimate of the flux of $\mathrm{CH}_{4}$ from seeps to the water column (3.60 to $4.28 \mathrm{Tg} \mathrm{CH}_{4} \mathrm{yr}^{-1}$ ) and atmosphere (0.05 to $\left.0.21 \mathrm{Tg} \mathrm{CH}_{4} \mathrm{yr}^{-1}\right)$.

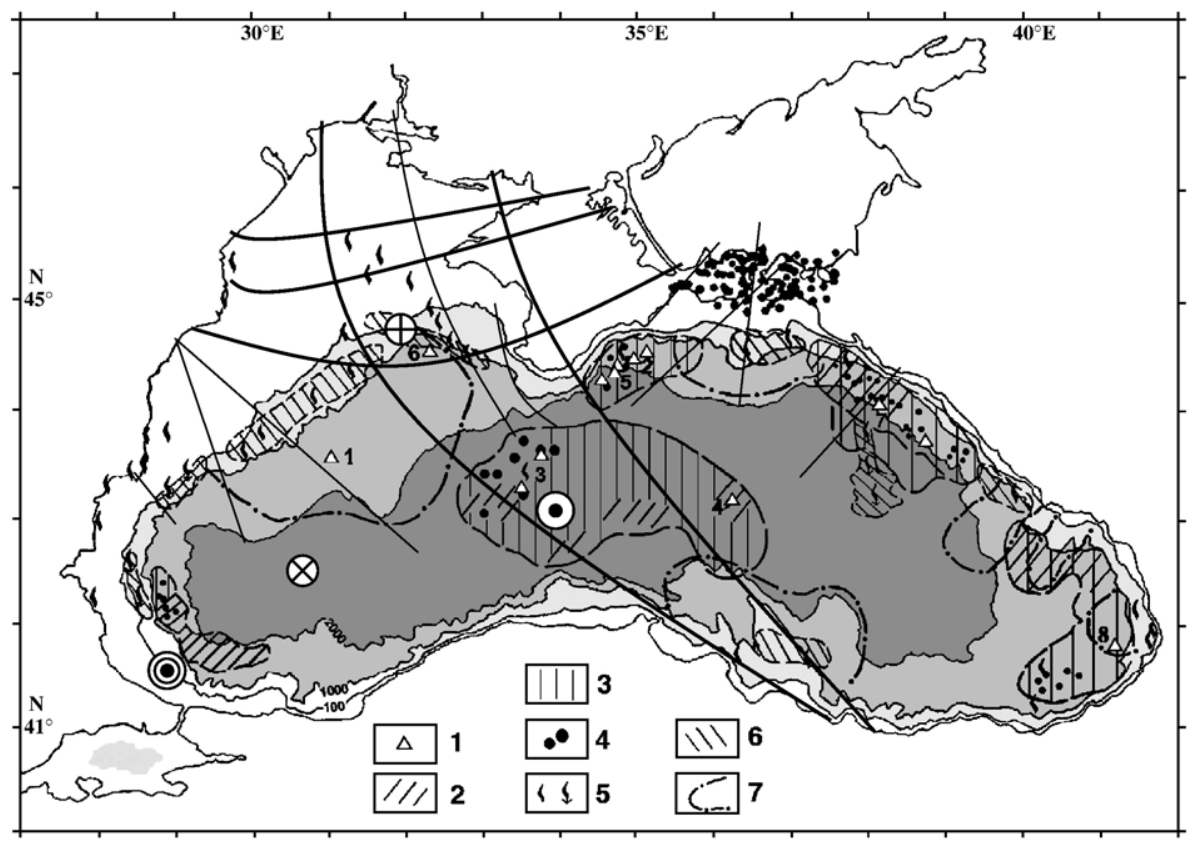

Fig. 1. Black Sea sampling locations and deep faults. (๑) July 1988 sample site $\left(\mathrm{CH}_{4}\right.$ concentration, $\mathrm{CH}_{4}$ oxidation rates, and $\left.\delta^{13} \mathrm{C}-\mathrm{CH} 4\right)[1,50] ;(\odot)$ July 1988 shelf sample site $\left(\mathrm{CH}_{4}\right.$ concentration in sediment); $(\otimes)$ May 2001 sample site (water column: $\mathrm{CH}_{4}$ concentration, $\left.\delta^{13} \mathrm{C}-\mathrm{CH}_{4},{ }^{14} \mathrm{C}-\mathrm{CH}_{4}\right)$; and $(\oplus)$ September 2004 sample site (seep gas collection). The map is from Vassilev and Dimitrov [12] with the following symbols: (1) Gas hydrate sampling (see Table 1 in Vassilev and Dimitrov [12] for numbering); (2) areas with seismic indications of gas hydrates; (3) areas of high gas hydrates prospect; (4) mud volcanoes; (5) areas of intensive fluid discharging; (6) gas seepage and seabed pockmarks; (7) mine submarine fans. The solid lines are deep faults interpolated after Kutas et al. [64]. 
Table 1

Sampling stations and measurements

\begin{tabular}{|c|c|c|c|c|c|}
\hline Station & Location & $\begin{array}{l}\text { Water depth } \\
(\mathrm{m})\end{array}$ & Sampling date & Measurements & Purpose \\
\hline Central basin & $\begin{array}{l}43^{\circ} 05^{\prime} \mathrm{N} \\
34^{\circ} 00^{\prime} \mathrm{E}\end{array}$ & 2200 & July, $1988[1,50]$ & $\begin{array}{l}\text { Water column: } \mathrm{CH}_{4} \text { concentration, } \\
\text { AOM rates, and } \delta^{13} \mathrm{C}-\mathrm{CH}_{4} \\
\text { Sediment: } \mathrm{CH}_{4} \text { concentration } \\
\text { and } \mathrm{AOM} \text { rates }\end{array}$ & $\begin{array}{l}\text { Estimating total Black Sea } \\
\mathrm{CH}_{4} \text { budget }\end{array}$ \\
\hline Shelf Station & $\begin{array}{l}41^{\circ} 35.5^{\prime} \mathrm{N} \\
28^{\circ} 56.92^{\prime} \mathrm{E}\end{array}$ & 170 & July, 1988 [1] & Sediment: $\mathrm{CH}_{4}$ concentration & \\
\hline Western basin & $\begin{array}{l}42^{\circ} 30.21^{\prime} \mathrm{N} \\
30^{\circ} 45.21^{\prime} \mathrm{E}\end{array}$ & 2100 & May-June, 2001 & $\begin{array}{l}\text { Water column: } \mathrm{CH}_{4} \text { concentration, } \\
\delta^{13} \mathrm{C}-\mathrm{CH}_{4} \text { and }{ }^{14} \mathrm{C}-\mathrm{CH}_{4}\end{array}$ & \multirow{2}{*}{$\begin{array}{l}\text { Determining the sources } \\
\text { of } \mathrm{CH}_{4} \text { to the water column } \\
\text { to partition the Black Sea } \\
\text { total } \mathrm{CH}_{4} \text { budget }\end{array}$} \\
\hline N.W. Shelf & $\begin{array}{l}44^{\circ} 46.48^{\prime} \mathrm{N} \\
31^{\circ} 59.42^{\prime} \mathrm{E}\end{array}$ & 222 & September, 2004 & Seep: $\delta^{13} \mathrm{C}-\mathrm{CH}_{4}$ and ${ }^{14} \mathrm{C}-\mathrm{CH}_{4}$ & \\
\hline
\end{tabular}

The modeling studies involved modifying a timedependent geochemical box model [28] to include a source term for $\mathrm{CH}_{4}$ emitted from seeps and adhere to the parameters of the Black Sea. The modeling results estimate depth distributions and magnitudes (4.95 to $5.65 \mathrm{Tg} \mathrm{CH}_{4} \mathrm{yr}^{-1}$ ) of the input of $\mathrm{CH}_{4}$ from seeps to the water column.

\section{Results and discussion}

\subsection{Measuring the flux of methane from seeps}

\subsubsection{Total methane budget}

The total Black Sea $\mathrm{CH}_{4}$ budget was assembled from $\mathrm{CH}_{4}$ concentration and anaerobic oxidation of $\mathrm{CH}_{4}$ (AOM) rate measurements made during the 1988 U.S.Turkey Black Sea Expedition [1] (Table 1). Measurements of $\mathrm{CH}_{4}$ dissolved in the water column (concentration and AOM rates) were restricted to a central station $\left(43^{\circ} 05^{\prime} \mathrm{N}\right.$, $34^{\circ} 00^{\prime} \mathrm{E}, 2200 \mathrm{~m}$ depth) well-removed from shelves, and were intended to represent a basin-wide integration of processes affecting the Black Sea $\mathrm{CH}_{4}$ distribution and budget. Distributions of $\mathrm{CH}_{4}$ concentration in sediment cores were measured at a shelf station $\left(41^{\circ} 35.5^{\prime} \mathrm{N}, 28^{\circ}\right.$ $56.92^{\prime} \mathrm{E}, 170 \mathrm{~m}$ depth) and a deep station $\left(43^{\circ} 04.82^{\prime} \mathrm{N}\right.$, $33^{\circ} 58.88^{\prime} \mathrm{E}, 2212 \mathrm{~m}$ depth) (Fig. 1). Water column profiles of $\mathrm{CH}_{4}$ concentration and $\mathrm{AOM}$ rates were assumed to represent average Black Sea values so that a first-order estimate of the Black Sea $\mathrm{CH}_{4}$ budget could be established. This budget was based on the following sinks of $\mathrm{CH}_{4}$ : measured water column and sediment rates of AOM, calculated gas evasion rates to the atmosphere, and export by the Bosporus outflow (Table 2). Reeburgh et al. [1] determined that the dominant sink of $\mathrm{CH}_{4}, \mathrm{AOM}$ in the water column, is about 70-fold larger than the next largest sink of $\mathrm{CH}_{4}$, evasion at the air: sea interface.

This budget assumed that the $\mathrm{CH}_{4}$ concentration in the waters of the Black Sea is in steady-state [1], so the total loss of $\mathrm{CH}_{4}$ must be balanced with a $\mathrm{CH}_{4}$ source of the same magnitude (Table 2). Only $\mathrm{CH}_{4}$ produced diagenetically in sediments was considered a source in the original budget [1]. Thermodynamic arguments indicate that there can be no large-scale production of $\mathrm{CH}_{4}$ in the water column so long as sulfate reduction is occurring [1,29,30]. Measurements by Albert et al. [31] show that sulfate reduction occurs in the water column of the Black Sea at nM day ${ }^{-1}$ rates, so we conclude that large-scale methanogenesis cannot occur in the anoxic Black Sea water column. A minor contribution of $\mathrm{CH}_{4}$ to the water column may be from zooplankton guts and

Table 2

Black Sea total methane budget [1]

\begin{tabular}{|c|c|}
\hline & $\mathrm{Tg} \mathrm{CH}_{4} \mathrm{yr}^{-1}$ \\
\hline \multicolumn{2}{|l|}{ Sinks } \\
\hline \multicolumn{2}{|l|}{ Evasion at the air: sea interface } \\
\hline Rate: $9.7 \mathrm{mmol} \mathrm{m}^{-2} \mathrm{yr}^{-1}$ & 0.066 \\
\hline \multicolumn{2}{|l|}{ Extent: $4.23 \times 10^{11} \mathrm{~m}^{2}$} \\
\hline \multicolumn{2}{|l|}{ Water column oxidation } \\
\hline \multicolumn{2}{|l|}{ Upper 100 m (aerobic/anaerobic) } \\
\hline Rate: $0.36 \mathrm{nM} \mathrm{yr}^{-1}$ & $3.0 \times 10^{-4}$ \\
\hline \multicolumn{2}{|l|}{ Extent: $5.3 \times 10^{16} \mathrm{~L}$} \\
\hline \multicolumn{2}{|l|}{ Below $100 \mathrm{~m}$ (anaerobic) } \\
\hline Rate: $0.6 \mu \mathrm{M} \mathrm{yr}^{-1}$ & 4.65 \\
\hline \multicolumn{2}{|l|}{ Extent: $4.8 \times 10^{17} \mathrm{~L}$} \\
\hline \multicolumn{2}{|l|}{ Oxidation by abyssal sediments } \\
\hline Rate: $0.1 \mathrm{mmol} \mathrm{m}^{-2} \mathrm{yr}^{-1}$ & $3.7 \times 10^{-4}$ \\
\hline \multicolumn{2}{|l|}{ Extent: $2.3 \times 10^{11} \mathrm{~m}^{2}$} \\
\hline \multicolumn{2}{|l|}{ Outflow at Bosporus } \\
\hline Rate: $1.9 \times 10^{14} \mathrm{~L} \mathrm{yr}^{-1}$ & $3.0 \times 10^{-5}$ \\
\hline \multicolumn{2}{|l|}{ Extent: $10 \mathrm{nM}$} \\
\hline \multicolumn{2}{|l|}{ Sources } \\
\hline \multicolumn{2}{|l|}{ Shelf/slope sediments $(100-1500 \mathrm{~m})$} \\
\hline Rate: $0.2 \mathrm{~mol} \mathrm{~m}^{-2} \mathrm{yr}^{-1}$ & 0.35 \\
\hline \multicolumn{2}{|l|}{ Extent: $1.1 \times 10^{11} \mathrm{~m}^{2}$} \\
\hline Seeps and clathrates (from this study: & 3.60 to 5.65 \\
\hline combined measurement and modeling results) & \\
\hline Rate: 0.53 to $0.84 \mathrm{~mol} \mathrm{~m}^{-2} \mathrm{yr}^{-1}$ & \\
\hline
\end{tabular}


fecal pellet microenvironments [32-34]. Globally, only $\mathrm{nM}$ water column $\mathrm{CH}_{4}$ concentrations have been reported from these sources [35-42]. Given the relatively high Black Sea water column $\mathrm{CH}_{4}$ concentrations $(\mu \mathrm{M})$ (Fig. 2), zooplankton guts and fecal pellet microenvironments likely provide $\leq 1 \%$ of the total source of $\mathrm{CH}_{4}$ to the water column.

At the shelf station, the $\mathrm{CH}_{4}$ concentration measured in a sediment core displayed a concave up distribution which shows that AOM is occurring [43]. A small positive $\mathrm{CH}_{4}$ concentration gradient between the surface sediments and the water column indicates that sediments on the shelf are a source of $\mathrm{CH}_{4}$ to the water column. In contrast, $\mathrm{CH}_{4}$ concentrations in sediments at the deep station are lower than in the adjacent overlying waters, indicating that these sediments are consuming $\mathrm{CH}_{4}$ from the water column. This was confirmed by AOM rate measurements using ${ }^{14} \mathrm{C}$-labelled $\mathrm{CH}_{4}[1]$. The Reeburgh et al. budget assumed that sediments below the anoxic: oxic interface $(100 \mathrm{~m})$ and above the continental slopeabyssal plane transition $(1500 \mathrm{~m})$ were the source of $\mathrm{CH}_{4}$ to the water column [1]. Given this source interval, a flux of $\mathrm{CH}_{4}$ from sediments of $1.5 \mathrm{~mol} \mathrm{~m}^{-2} \mathrm{yr}^{-1}$ is needed to balance the sinks and maintain a steady-state $\mathrm{CH}_{4}$ concentration in the water column. However, they determined the flux of $\mathrm{CH}_{4}$ from the shelf core to be $0.2 \mathrm{~mol} \mathrm{~m}^{-2} \mathrm{yr}^{-1}$ leaving $86.7 \%$ of the balancing source flux not quantified [1]. Subsequent measurements of $\mathrm{CH}_{4}$ concentration profiles in sediment cores $[5,6]$ indicate that the diffusive flux of $\mathrm{CH}_{4}$ from sediments to the water
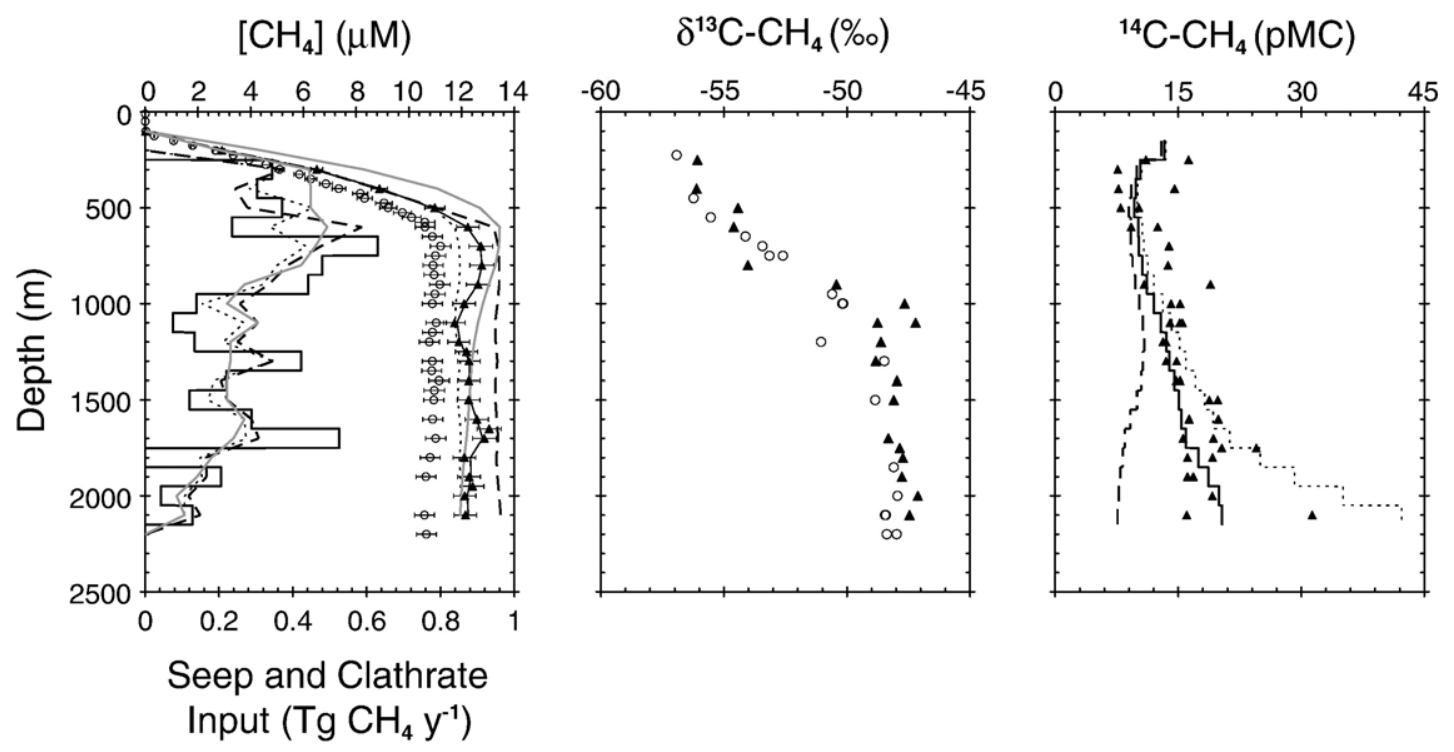

Fig. 2. Measured Black Sea $\mathrm{CH}_{4}$ concentration $(\mu \mathrm{M})$ and isotope $\left(\delta^{13} \mathrm{C}-\mathrm{CH}_{4}\right.$ and $\left.{ }^{14} \mathrm{C}-\mathrm{CH}_{4}\right)$ data in the water column. The $\delta^{13} \mathrm{C}-\mathrm{CH} \mathrm{H}_{4}$ data is expressed vs. VPDB (Vienna Peedee belemnite) standard. The ${ }^{14} \mathrm{C}-\mathrm{CH}_{4}$ data is expressed as percent Modern Carbon (pMC) [47]. By convention [47], all radiocarbon results are normalized to ${ }^{13} \mathrm{C}$. Samples were collected in the (O) central Black Sea water column in July 1988 [1,50] and $(\mathbf{\Delta})$ western Black Sea water column in May 2001. Precision of $\pm 1 \sigma$ for the: 1) $\mathrm{CH}_{4}$ concentration measurements is 3-4\% based on replicate analyses of samples, 2) $\delta^{13} \mathrm{C}-\mathrm{CH}_{4}$ measurements is $0.3 \%$ based on replicate analyses of standard samples, and 3) ${ }^{14} \mathrm{C}-\mathrm{CH}_{4}$ measurements is $0.1 \mathrm{pMC}$. Error bars for the $\delta^{13} \mathrm{C}-\mathrm{CH}_{4}$ and ${ }^{14} \mathrm{C}-\mathrm{CH}_{4}$ measurements are less than the width of the data points. A previously published multi-box model [28] was used to quantify the depth distributions of the inputs of $\mathrm{CH}_{4[\mathrm{~S}]}$ and to provide additional estimates of the basin-wide flux of $\mathrm{CH}_{4[\mathrm{~S}]}$. This model was modified to have box thicknesses of $100 \mathrm{~m}$, to not consider depths less than $150 \mathrm{~m}$ due to low water column $\mathrm{CH}_{4}$ concentrations and oxic conditions in the shallow surface waters, and to match the parameters of the Black Sea (bathymetry and eddy diffusion coefficients). The model was initiated with no $\mathrm{CH}_{4}$ in the basin and was run for $200 \mathrm{yr}$ to reach steady-state. The inputs of $\mathrm{CH}_{4[\mathrm{~S}]}$ were varied until the modeled $\mathrm{CH}_{4}$ concentration profile matched the measurements made in year 2001. LEFT PANEL: The model was assigned inputs of $\mathrm{CH}_{4[\mathrm{D}]}(150-1550 \mathrm{~m}$ : 0.2 mol m${ }^{-2} \mathrm{yr}^{-1}, 1550-2050 \mathrm{~m}: 0.1 \mathrm{~mol} \mathrm{~m}^{-2} \mathrm{yr}^{-1}, 2050-2150 \mathrm{~m}: 0.02 \mathrm{~mol} \mathrm{~m}^{-2} \mathrm{yr}^{-1}$ ). The following model results are displayed for $\mathrm{CH}_{4}$ concentration and inputs of $\mathrm{CH}_{4[\mathrm{~S}]}$ : (solid black line) model dependent upon the $\mathrm{CH}_{4}$ concentration data represented by $(\boldsymbol{\Delta})$, (dashed line) model dependent upon a uniform $\mathrm{CH}_{4}$ concentration profile of $13.32 \mu \mathrm{M}$ below $700 \mathrm{~m}$ depth, (dotted line) model dependent upon a uniform $\mathrm{CH}_{4}$ concentration profile of $11.82 \mu \mathrm{M}$ below $700 \mathrm{~m}$ depth, (solid gray line) model dependent upon average values of $\mathrm{CH}_{4}$ concentration. The inputs of seep and clathrate $\mathrm{CH}_{4}$ represented by the dashed, dotted, and solid gray lines are not plotted in histogram style only to increase legibility. RIGHT PANEL: The model was dependent upon the $\mathrm{CH}_{4}$ concentration data represented by $(\boldsymbol{\Delta})$ in the left panel. The solid black line represents the model results with the assigned inputs of $\mathrm{CH}_{4[\mathrm{D}]}$ used in the left panel. The dashed line represents the model results with the assigned inputs of $\mathrm{CH}_{4[\mathrm{D}]}$ as suggested by Reeburgh et al. [1]. The dotted line represents the model results with the assigned inputs of $\mathrm{CH}_{4[\mathrm{D}]}$ as suggested by Reeburgh et al. [1] and with an additional input of $0.2 \mathrm{~mol} \mathrm{CH}_{4} \mathrm{~m}^{-2} \mathrm{yr}^{-1}$ from 2050 to $2150 \mathrm{~m}$. 
column may be even smaller. How the $\mathrm{CH}_{4}$ concentration and $\mathrm{AOM}$ rate distributions in the water column are maintained with this small diffusive source of $\mathrm{CH}_{4}$ from sediments is a major puzzle. The recently reported seeps [7-14] appear to provide the balancing flux of $\mathrm{CH}_{4}$.

\subsubsection{Methane concentration, $\delta^{13} \mathrm{C}$, and radiocarbon measurements}

Water samples were collected from May 26 to June 3, 2001 , on board the $R / V$ Knorr within a $4.24 \mathrm{~km}$ radius of a station located in the western section of the Black Sea $\left(42^{\circ} 30.21^{\prime} \mathrm{N}, 30^{\circ} 45.21^{\prime} \mathrm{E}, 2100 \mathrm{~m}\right)$ (Table 1, Fig. 1). Concentrations of $\mathrm{CH}_{4}(\mu \mathrm{M})$ were measured with a headspace equilibration technique based on Henry's Law. Samples were prepared for seawater $\mathrm{CH}_{4}$ concentration analyses by filling $120 \mathrm{cc}$ serum vials directly from Niskin bottles. After the seawater vials were sealed with stoppers and crimp caps, a 10 cc headspace of ultrahigh-purity helium was introduced by displacing an equivalent volume of sample. The vials were vigorously shaken and allowed to equilibrate for $12 \mathrm{~h}$. Shipboard $\mathrm{CH}_{4}$ concentration analyses were performed by analyzing two $5 \mathrm{cc}$ aliquots of the headspace with gas chromatography and flame ionization detection (GC-Mini 2; Shimadzu Corp). The results have been corrected for the amount of $\mathrm{CH}_{4}$ still dissolved in solution using Bunsen solubility coefficients established by Yamamoto et al. [44] (Fig. 2).

Lamont radon stripping boards $[45,46]$ were modified to quantitatively extract and trap the $\mathrm{CH}_{4}$ dissolved in seawater for natural isotopic analysis. For each sample, an evacuated $20 \mathrm{~L}$ glass carboy was filled with 19 L of seawater directly from Niskin bottles. The carboy was connected to a stripping board which circulated helium through the seawater sample to extract the dissolved $\mathrm{CH}_{4}$. The extracted $\mathrm{CH}_{4}$ was trapped at liquid nitrogen temperature in a stainless steel U-trap, filled with a molecular sieve. (Due to low water column concentrations of $\mathrm{CH}_{4}$ at and above 300 $\mathrm{m}$ water depth, $\mathrm{CH}_{4}$ was extracted from two carboys $(38 \mathrm{~L})$ for the shallowest samples.) The traps were returned to UC Irvine where the $\mathrm{CH}_{4}$ was extracted, purified, and analyzed for the natural content of ${ }^{13} \mathrm{C}$ and radiocarbon. The entire $\mathrm{CH}_{4}$ collection, extraction, and analysis procedures are quantitative and the backgrounds are small $\left(0.52_{8} \pm 0.39 \mu \mathrm{mol}\right.$ of $\mathrm{CH}_{4}$ with radiocarbon content ${ }^{14} \mathrm{C} / \mathrm{C}=96.1 \pm 0.3 \mathrm{pMC}$ (percent Modern Carbon) [47]) relative to the average sample size $(228 \mu \mathrm{mol})$. Details of the isotope procedures (apparatus, techniques, blank determinations, precision, and the lack of isotope fractionation) are presented in Kessler and Reeburgh [48].
Gas emitted from seeps was collected from September 10 to 26, 2004, on board the $F / S$ Poseidon with the submersible $J A G O$. Gas from five seeps located around $44^{\circ} 46.48^{\prime} \mathrm{N}, 31^{\circ} 59.42^{\prime} \mathrm{E}$ (average depth of $222 \mathrm{~m}$ ) was sampled (Table 1, Fig. 1) and the isotope procedures were adapted to analyze the seep gas for $\delta^{13} \mathrm{C}-\mathrm{CH}_{4}$ and ${ }^{14} \mathrm{C}-\mathrm{CH}_{4}[48]$.

Since there are no time-series data for the concentrations of $\mathrm{CH}_{4}$ at a single station in the Black Sea, we use the $\delta^{13} \mathrm{C}-\mathrm{CH}_{4}$ data to test the steady-state assumption in three separate investigations. First, a stable isotope equation, derived to describe an "open-system" where $\mathrm{CH}_{4}$ is continually added from seeps while simultaneously being removed by reaction, predicts that the Black Sea is in steady-state. When the measured values of $\delta^{13} \mathrm{C}-\mathrm{CH}_{4}$ emitted from seeps and dissolved in the water column are input into this equation, along with the isotopic fractionation factors for $\mathrm{AOM}$, this equation predicts that the rate at which $\mathrm{CH}_{4}$ is input from seeps equals the rate at which $\mathrm{CH}_{4}$ is removed by reaction [49]. Second, the concentration of $\mathrm{CH}_{4}$ dissolved in the water column is on average $11.5 \%$ higher is the western Black Sea (measured in 2001) than in the central Black Sea (measured in 1988) (Fig. 2). If we assume that the $\mathrm{CH}_{4}$ concentration values measured in 1988 and 2001 represent average values for the entire basin and not spatial heterogeneities in $\mathrm{CH}_{4}$ concentration, then the $\mathrm{CH}_{4}$ concentration has increased by $11.5 \%$ over a $13 \mathrm{yr}$ period. This increase in $\mathrm{CH}_{4}$ inventory would cause the $\delta^{13} \mathrm{C}$ of $\mathrm{CH}_{4}$ dissolved in the water column to decrease by $1.4 \pm 0.7 \%$ over this $13 \mathrm{yr}$ period [49]. While this difference is small, our measurements of $\delta^{13} \mathrm{C}-\mathrm{CH}_{4}$ are indistinguishable from those conducted $13 \mathrm{yr}$ ago [50] (Fig. 2). This suggests that the Black Sea is in steadystate with regard to $\mathrm{CH}_{4}$ and the $11.5 \%$ difference between the $\mathrm{CH}_{4}$ concentration profiles possibly displays the spatial heterogeneities of $\mathrm{CH}_{4}$ concentration (Figs. 1 and 2). Third, Tans [51] showed that the timescales for changes in the isotope ratio and the large-scale spatial isotopic gradients of a reservoir are often longer than they are for changes in total $\mathrm{CH}_{4}$ concentration (i.e. isotopic steady-state is reached after concentration steady-state). Since our $\delta^{13} \mathrm{C}-\mathrm{CH}_{4}$ results show no temporal (1988 to 2001) or spatial (central to western Black Sea) variation, the steady-state assumption in the Black Sea $\mathrm{CH}_{4}$ budget [1] may be appropriate. The possibility exists of non-steady-state conditions above the shallow shelves $(0-500 \mathrm{~m}$ depth) where episodic intrusions of $\mathrm{CH}_{4}$ from seeps influence the water column $\mathrm{CH}_{4}$ concentration. However, this region of possible non-steady-state accounts for only $3 \%$ of the total volume of the Black Sea [52]. 
The source of $\mathrm{CH}_{4}$ dissolved in the Black Sea water column is dominated by $\mathrm{CH}_{4}$ that is radiocarbon-free (fossil; pMC=0), but also contains a smaller source of $\mathrm{CH}_{4}$ with relatively modern contents of radiocarbon (Fig. 2). The concentration weighted average of the ${ }^{14} \mathrm{C}-\mathrm{CH}_{4}$ data in the water column is $15.7_{2} \pm 6.7_{5} \mathrm{pMC}$ (Eq. 1).

$\mathrm{pMC}_{\mathrm{Ave}}=\frac{\sum\left(\left[\mathrm{CH}_{4}\right]_{i} \times V_{i} \times \mathrm{pMC}_{i}\right)}{\sum\left(\left[\mathrm{CH}_{4}\right]_{i} \times V_{i}\right)}$

Here, $\left[\mathrm{CH}_{4}\right]_{i}, V_{i}$, and $\mathrm{pMC}_{i}$ are the $\mathrm{CH}_{4}$ concentration, percent volume [52], and ${ }^{14} \mathrm{C}-\mathrm{CH}_{4}$, respectively, in the depth interval $i$.

The results of our ${ }^{14} \mathrm{C}-\mathrm{CH}_{4}$ measurements on gas emitted from seeps were unexpected; all samples of $\mathrm{CH}_{4}$ emitted from seeps $\left(\mathrm{CH}_{4[\mathrm{~S}]}\right)$ contain measurable amounts of radiocarbon $\left(5.0_{2} \pm 0.4 \mathrm{pMC} ; 24 \mathrm{kA}{ }^{14} \mathrm{C} \mathrm{BP}\right.$ (thousand radiocarbon years Before Present)). We have no explanation for this finding; a possible reason why this $\mathrm{CH}_{4[\mathrm{~S}]}$ is not radiocarbon-free is that $\mathrm{CH}_{4}$, generated from late Eocene source rock [53], acquires $\mathrm{CH}_{4}$ with modern radiocarbon contents during transit through recently deposited sediments. Gulin et al. [8] indirectly estimated the radiocarbon content of Black Sea $\mathrm{CH}_{4[\mathrm{~S}]}$ assuming that carbonate in structures formed around $\mathrm{CH}_{4}$ seeps [10] is formed from a mixture of seawater bicarbonate and the product of AOM. Their results (8.5 to $10.6 \mathrm{kA}{ }^{14} \mathrm{C} \mathrm{BP}$ or 34.7 to $26.7 \mathrm{pMC}$ ) were calculated from measurements of $\mathrm{CH}_{4}\left(\delta^{13} \mathrm{C}\right)$, seawater bicarbonate $\left(\delta^{13} \mathrm{C}\right.$ and radiocarbon), and the carbonate structures formed around $230 \mathrm{~m}$ deep $\mathrm{CH}_{4}$ seeps $\left(\delta^{13} \mathrm{C}\right.$ and radiocarbon) located ca. $26 \mathrm{~km}$ south-east of our seep site. The process of anaerobically oxidizing $\mathrm{CH}_{4}$ to total $\mathrm{CO}_{2}$ causes significant isotopic fractionation in both the reactant and the product. Equations describing the isotopic content of the reactant and product were established by Bigeleisen and Wolfsberg [54] and the isotopic fraction factors specific to AOM have been previously quantified $[49,55,56]$. Gulin et al. [8] did not account for isotopic fractionation caused by $\mathrm{AOM}$ and their range of $\delta^{13} \mathrm{C}$ values of Black Sea carbonate structures did not include other reports of values up to $10 \%$ heavier $[10,13]$. These two factors cause the upper range reported by Gulin et al. [8] to increase to $18.2 \mathrm{kA}{ }^{14} \mathrm{C} \mathrm{BP}$ (or $10.4 \mathrm{pMC}$ ), and show how sensitive their indirect analysis is to parameter changes.

There are no ${ }^{14} \mathrm{C}-\mathrm{CH}_{4}$ measurements in the Black Sea of $\mathrm{CH}_{4}$ produced diagenetically in sediments $\left(\mathrm{CH}_{4[\mathrm{D}]}\right)$. However, $\mathrm{CH}_{4}$ formed at relatively shallow depths in sediments can diffuse into the water column and should contain measurable amounts of radiocarbon $(\mathrm{pMC}>0)$ and possibly a radiocarbon content influenced by atmospheric nuclear weapons testing ( $\mathrm{pMC}>100$ ). Recent ${ }^{14} \mathrm{C}-\mathrm{CH}_{4}$ measurements in the sediments of the Cariaco Basin [57] and Skan Bay, AK [27] show that nearmodern radiocarbon values are found in near-surface sediments and the ${ }^{14} \mathrm{C}$ content decreases with depth; this indicates that $\mathrm{CH}_{4}$ is produced locally and is not dominated by $\mathrm{CH}_{4}$ diffusing up from deep sediments $[55,58]$. Previous radiocarbon measurements aimed at determining the Black Sea sediment chronology show that in the interval of 0 to $50 \mathrm{~cm}$ depth, the total organic carbon and total carbonate carbon ranges from 105 to $63 \mathrm{pMC}$ $[59,60]$. Decadal turnover times for $\mathrm{CH}_{4[\mathrm{D}]}$, determined from concentration and oxidation rate measurements of $\mathrm{CH}_{4}[1,5,6]$, indicate that $\mathrm{CH}_{4[\mathrm{D}]}$ likely has a similar radiocarbon signature to its substrates, the total carbon material. Since $\mathrm{CH}_{4}$ dissolved in the Black Sea water column also has decadal turnover times $[1]$, the ${ }^{14} \mathrm{C}-$ $\mathrm{CH}_{4}$ results indicate that the source of $\mathrm{CH}_{4}$ to the water column is a mixture of $\mathrm{CH}_{4[\mathrm{~S}]}$ and $\mathrm{CH}_{4[\mathrm{D}]}$.

\subsubsection{Partitioning the total flux of methane to the water column}

To estimate the magnitude of the flux of $\mathrm{CH}_{4[\mathrm{~S}]}$ to the water column, first we determine the fraction of the total source of $\mathrm{CH}_{4}$ to the water column that is emitted from seeps and then we multiply that fraction by the total flux of Black Sea $\mathrm{CH}_{4}$ to the water column (4.72 $\mathrm{Tg} \mathrm{yr}^{-1}=$ sum of the sinks in Table 2). We used a radiocarbon isotopic mass balance to determine the fraction of the total $\mathrm{CH}_{4}$ source this is emitted from seeps (Eq. 2).

$\mathrm{pMC}_{\mathrm{S}} \times F+\mathrm{pMC}_{\mathrm{D}} \times(1-F)=\mathrm{pMC}_{\mathrm{W}}$

Here, $F$ is the fraction of the source of $\mathrm{CH}_{4}$ that is emitted from seeps and $\mathrm{pMC}_{\mathrm{S}}, \mathrm{pMC}_{\mathrm{D}}$, and $\mathrm{pMC}_{\mathrm{W}}$ are the ${ }^{14} \mathrm{C}-\mathrm{CH}_{4}$ contents of $\mathrm{CH}_{4[\mathrm{~S}]}\left(5.0_{2} \pm 0.4 \mathrm{pMC}\right)$,

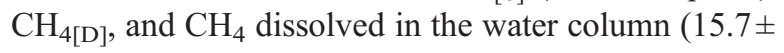
$6.7_{5} \mathrm{pMC}$ ), respectively. We have no direct measurements of the ${ }^{14} \mathrm{C}-\mathrm{CH}_{4}$ content of $\mathrm{CH}_{4[\mathrm{D}]}$. Based on radiocarbon measurements of total organic and carbonate carbon in the sediment $[59,60]$, the most likely radiocarbon content of $\mathrm{CH}_{4[\mathrm{D}]}$ is between 63 and $105 \mathrm{pMC}$. We have placed conservative bounds on the radiocarbon signature of $\mathrm{CH}_{4[\mathrm{D}]}$ in the four cases presented in Table 3. This analysis indicates that the basin-wide flux of $\mathrm{CH}_{4[\mathrm{~S}]}$ to the water column is likely between 3.60 and 4.28 $\mathrm{Tg} \mathrm{CH}_{4} \mathrm{yr}^{-1}$ (Table 3).

For $\mathrm{CH}_{4}$ dissolved in the near surface waters of the Black Sea, $0.066 \mathrm{Tg} \mathrm{yr}^{-1}$ evade into the atmosphere (Table 2) [1]. The average ${ }^{14} \mathrm{C}-\mathrm{CH}_{4}$ content in the 
Table 3

Estimates of inputs of $\mathrm{CH}_{4[\mathrm{~S}]}$ in the Black Sea based on radiocarbon measurements

\begin{tabular}{lcccc}
\hline $\begin{array}{l}\text { Methane Input } \\
\left(\mathrm{Tg} \mathrm{yr}^{-1}\right)\end{array}$ & \multicolumn{4}{c}{ Assumed $\mathrm{CH}_{4[\mathrm{D}]}$ percent Modern Carbon (pMC) } \\
\cline { 2 - 5 } & 120 & 100 & 75 & 50 \\
\hline To water column & $4.28 \pm 0.27$ & $4.19 \pm 0.32$ & $4.00 \pm 0.42$ & $3.60 \pm 0.64$ \\
To atmosphere & $0.061 \pm 0.002$ & $0.060 \pm 0.002$ & $0.058 \pm 0.003$ & $0.053 \pm 0.005$ \\
\hline
\end{tabular}

surface $250 \mathrm{~m}$ of the water column is $13.7 \pm 3.7 \mathrm{pMC}$. We estimate a range of fluxes of $\mathrm{CH}_{4[\mathrm{~S}]}$ to the atmosphere in the Black Sea (Table 3) for $\mathrm{CH}_{4}$ dissolved in the near surface waters that evades to the atmosphere $(0.05$ to

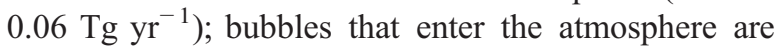
not considered in this estimate. Dimitrov [7] found this to be a substantial flux ( 0.03 to $\left.0.15 \mathrm{Tg} \mathrm{CH}_{4} \mathrm{yr}^{-1}\right)$ compared with our flux of dissolved $\mathrm{CH}_{4}$, so to account for the shallow water bubble flux, we adjust the total flux of $\mathrm{CH}_{4[\mathrm{~S}]}$ to the atmosphere in the Black Sea to 0.05 to $0.21 \mathrm{Tg} \mathrm{yr}^{-1}$.

\subsection{Modeling the flux of methane from seeps}

We apply a time-dependent geochemical box model [28] to the anoxic region (150-2150 m depth) of the Black Sea to quantify the depth distribution of inputs of $\mathrm{CH}_{4[\mathrm{~S}]}$ as well as to provide an additional estimate of the basin-wide input of $\mathrm{CH}_{4[\mathrm{~S}]}$. The model includes a source term for $\mathrm{CH}_{4[\mathrm{~S}]}$, assumes the concentration of $\mathrm{CH}_{4}$ dissolved in the water column is in steady-state, uses the Black Sea bathymetry [52], and assigns each box a thickness of $100 \mathrm{~m}$. The model incorporates the specific rate of AOM in the water column $\left(0.06 \mathrm{yr}^{-1}\right)$ [1]. (Rates of AOM in the water column have been shown to increase linearly with $\mathrm{CH}_{4}$ concentration [61]. Specific rates of $\mathrm{AOM}$ are normalized to $\mathrm{CH}_{4}$ concentration, so that they may be accurately applied to different concentration regions.) Also, the model includes a term for the consumption of $\mathrm{CH}_{4}$ from the water column by abyssal sediments $\left(0.1 \mathrm{mmol} \mathrm{m}^{-2} \mathrm{yr}^{-1}\right)$ (Table 2) [1]. Our multi-box model is one-dimensional (vertical), so the possibility exists that there are regions in the area defined by each box where $\mathrm{CH}_{4}$ is being inputted to the water column from sediments and separate regions where $\mathrm{CH}_{4}$ is being consumed from the water column by the sediments. Initially, we assigned inputs of $\mathrm{CH}_{4[\mathrm{D}]}$ to the water column over the depth interval of 150 to $1550 \mathrm{~m}$, at a rate of $0.2 \mathrm{~mol} \mathrm{~m}^{-2} \mathrm{yr}^{-1}$, as suggested by Reeburgh et al. [1] (Table 2).

The model was initiated with no $\mathrm{CH}_{4}$ in the Black Sea water column and was run for $200 \mathrm{yr}$ (time step $=0.1 \mathrm{yr}$ ), significantly longer than the model predicts is necessary to reach steady-state. The inputs of $\mathrm{CH}_{4[\mathrm{~S}]}$ were varied until the modeled concentrations of $\mathrm{CH}_{4}$ dissolved in the water column agreed with the year 2001 western Black Sea measurements to less than $0.6 \%$ on average. No isotopic data is input into the model, so the newly predicted inputs of $\mathrm{CH}_{4[\mathrm{~S}]}$ and the assigned values of $\mathrm{CH}_{4[\mathrm{D}]}$ can be used to model a ${ }^{14} \mathrm{C}-\mathrm{CH}_{4}$ profile in the water column (Fig. 2). This model predicts a ${ }^{14} \mathrm{C}-\mathrm{CH}_{4}$ profile containing significantly less radiocarbon than our measurements in the deep Black Sea. We conclude that the deep waters of the Black Sea must have an additional source of $\mathrm{CH}_{4}$ with relatively modern radiocarbon contents. To account for this additional source of relatively "modern" $\mathrm{CH}_{4}$, we conducted two modeling experiments where we manually increased the deep basin sources of $\mathrm{CH}_{4[\mathrm{D}]}$ beyond what was suggested by Reeburgh et al. [1] (Fig. 2.).

Inputs of $\mathrm{CH}_{4[\mathrm{~S}]}$ are predicted at most depths between 250 and $2150 \mathrm{~m}$ (Fig. 2), consistent with the distribution of known seeps, clathrates, mud volcanoes, and seabed pockmarks (Fig. 1) $[8,12,14]$. The modelpredicted input profile of $\mathrm{CH}_{4[\mathrm{~S}]}$ shows local maxima or minima at 700,1100, and $1700 \mathrm{~m}$ depth consistent with congruent fluctuations in the mean values of $\mathrm{CH}_{4}$ concentration at similar depths. However, the uncertainty in our concentration measurements is such that a uniform $\mathrm{CH}_{4}$ concentration profile below $700 \mathrm{~m}$ depth is possible. To account for this possibility, we have conducted two additional modeling experiments dependent upon uniform $\mathrm{CH}_{4}$ concentration values (below $700 \mathrm{~m}$ depth) at either the lower end $(11.82 \mu \mathrm{M})$ or the upper end $(13.32 \mu \mathrm{M})$ of the standard deviations of our $\mathrm{CH}_{4}$ concentration measurements. These "uniform $\mathrm{CH}_{4}$ concentration" models predict more uniform distributions for the inputs of $\mathrm{CH}_{4[\mathrm{~S}]}$ (Fig. 2).

Due to the large predicted inputs of $\mathrm{CH}_{4[\mathrm{~S}]}$, this model is relatively insensitive to the water column eddy diffusion coefficients. Changing the eddy diffusion coefficients from 1 to $4 \mathrm{~cm}^{2} \mathrm{~s}^{-1}$ in the anoxic region of the Black Sea only changes the final results by $3.7 \%$ on average. Also, $\mathrm{CH}_{4[\mathrm{~S}]}$ released below the clathrate stability zone $(700 \mathrm{~m})$ will partially resist dissolution due to the formation of a clathrate mantle around the bubbles [62]. If $\mathrm{CH}_{4[\mathrm{~S}]}$ only dissolved in waters above $700 \mathrm{~m}$ depth, eddy diffusion in the water column could not 
maintain $\mathrm{CH}_{4}$ concentration and radiocarbon profiles, so bubbles must dissolve in deep waters or $\mathrm{CH}_{4}$ must be added in solution.

Averaged over the entire basin, our results indicate that 4.95 to $5.65 \mathrm{Tg} \mathrm{yr}^{-1}$ (0.73 to $\left.0.84 \mathrm{~mol} \mathrm{~m}^{-2} \mathrm{yr}^{-1}\right)$ of $\mathrm{CH}_{4[\mathrm{~S}]}$ are being added to the water column. Since this multi-box model is one-dimensional (vertical), it assumes that the $\mathrm{CH}_{4}$ concentration profile measured in the western Black Sea water column is representative of average values for the entire basin. In Section 2.1. Measuring the flux of methane from seeps, we assumed that the $\mathrm{CH}_{4}$ concentration profile measured in the central Black Sea water column is representative of average values for the entire basin, again to estimate the basin-wide inputs of $\mathrm{CH}_{4[\mathrm{~S}]}$. Since the $\mathrm{CH}_{4}$ concentration profile measured in the western Black Sea water column is on average $11.5 \%$ greater than in the central Black Sea, these separate estimates of the basin-wide inputs of $\mathrm{CH}_{4[\mathrm{~S}]}$ likely bound the true value.

\section{Conclusions}

The contribution of decomposing clathrates to the global $\mathrm{CH}_{4}$ budget remains a major uncertainty [63]. Substantial microbial oxidation in adjacent sediments and overlying waters precludes the use of stable isotopes of $\mathrm{CH}_{4}$ to identify the fraction of $\mathrm{CH}_{4}$ dissolved in the water column or sediment that is released from clathrates. Rehder et al. [19] measured the rate of dissolution of synthetic $\mathrm{CH}_{4}$ clathrate in the clathrate stability zone $(\mathrm{P}, \mathrm{T})$ in an advecting field of seawater that was undersaturated with respect to $\mathrm{CH}_{4}$ concentration. Since natural clathrates are usually located within a sediment matrix surrounded by $\mathrm{CH}_{4}$-rich or $\mathrm{CH}_{4}$ saturated fluids, the Rehder et al. rates place an upper bound on the decomposing clathrate contribution $\left(11670 \pm 950 \mathrm{~mol} \mathrm{CH}_{4} \mathrm{~m}^{-2} \mathrm{yr}^{-1}\right)$. Presuming the fluxes of $\mathrm{CH}_{4[\mathrm{~S}]}$ estimated in this study are all of clathrate origin, the Black Sea clathrate decomposition rate is 0.53 to $0.84 \mathrm{~mol} \mathrm{CH}_{4} \mathrm{~m}^{-2} \mathrm{yr}^{-1}$, or $10^{5}$-fold smaller.

In conclusion, we have estimated the basin-wide flux of $\mathrm{CH}_{4}$ emitted from seeps and decomposing clathrates to the water column and atmosphere in the Black Sea. The radiocarbon results indicate that the flux of $\mathrm{CH}_{4}$ to the water column is dominated by emissions from seeps and decomposing clathrates. Our measurements and modeling studies indicate that between 3.60 to $5.65 \mathrm{Tg}$ $\mathrm{yr}^{-1}$ of $\mathrm{CH}_{4}$ emitted from seeps and decomposing clathrates enter the Black Sea water column and 0.05 to $0.21 \mathrm{Tg} \mathrm{yr}^{-1}$ escape to the atmosphere. These estimates of the fluxes of $\mathrm{CH}_{4}$ emitted from seeps and decomposing clathrates to the Black Sea may be refined with long term sampling programs; multiple sites can be established characterizing the entire Black Sea where high precision measurements of $\mathrm{CH}_{4}$ concentration, rates of $\mathrm{AOM}$, and natural isotopes of $\mathrm{CH}_{4}$ are routinely made.

\section{Acknowledgements}

We acknowledge the crews of the $R / V$ Knorr, $F / S$ Poseidon, and $J A G O$ for their enthusiasm and support at sea, Xiaomei Xu and Guaciara dos Santos for laboratory support, and David Valentine for scientific support at sea. (D. Valentine conducted all $\mathrm{CH}_{4}$ concentration analyses at sea.) This manuscript was improved by constructive and thorough reviews by an anonymous reviewer and the editor of Earth and Planetary Science Letters. This work was supported by the National Science Foundation (NSF Grant OCE-0096280 and OCE-0326928). This work was also supported by instrumentation awards (IRMS and AMS) by the W. M. Keck Foundation.

\section{References}

[1] W.S. Reeburgh, B.B. Ward, S.C. Whalen, K.A. Sandbeck, K.A. Kilpatrick, L.J. Kerkhof, Black Sea methane geochemistry, Deep-Sea Res. 38 (1991) S1189-S1210.

[2] D. Amouroux, G. Roberts, S. Rapsomanikis, M.O. Andreae, Biogenic gas $\left(\mathrm{CH}_{4}, \mathrm{~N}_{2} \mathrm{O}\right.$, DMS $)$ emission to the atmosphere from near-shore and shelf waters of the north-western Black Sea, Estuar. Coast. Shelf Sci. 54 (2002) 575-587.

[3] L.P. Atkinson, F.A. Richards, The occurrence and distribution of methane in the marine environment, Deep-Sea Res. 14 (1967) 673-684.

[4] J.M. Hunt, J.K. Whelan, Dissolved gases in Black Sea sediments, Initial Rep. Deep Sea Drill. Proj. 42 (1978) 661-665.

[5] M.V. Ivanov, N.V. Pimenov, I.I. Rusanov, A.Y. Lein, Microbial processes of the methane cycle at the north-western shelf of the Black Sea, Estuar. Coast. Shelf Sci. 54 (2002) 589-599.

[6] B.B. Jørgensen, A. Weber, J. Zopfi, Sulfate reduction and anaerobic methane oxidation in Black Sea sediments, Deep-Sea Res., Part 1, Oceanogr. Res. Pap. 48 (2001) 2097-2120.

[7] L. Dimitrov, Contribution to atmospheric methane by natural seepages on the Bulgarian continental shelf, Cont. Shelf Res. 22 (2002) 2429-2442.

[8] S.B. Gulin, G.G. Polikarpov, V.N. Egorov, The age of microbial carbonate structures grown at methane seeps in the Black Sea with an implication of dating of the seeping methane, Mar. Chem. 84 (2003) 67-72.

[9] C. Luth, U. Luth, A.V. Gebruk, H. Thiel, Methane gas seeps along the oxic/anoxic gradient in the Black Sea: manifestations, biogenic sediment compounds and preliminary results on benthic ecology, Mar. Ecol. 20 (1999) 221-249.

[10] W. Michaelis, R. Seifert, K. Nauhaus, T. Treude, V. Thiel, M. Blumenberg, K. Knittel, A. Gieseke, K. Peterknecht, T. Pape, A. Boetius, R. Amann, B.B. Jørgensen, F. Widdel, J. Peckmann, N.V. Pimenov, M.B. Gulin, Microbial reefs in the Black Sea fueled by anaerobic oxidation of methane, Science 297 (2002) 1013-1015. 
[11] G.D. Ginsburg, A.N. Kremlev, M.N. Grigor'ev, G.V. Larkin, A.D. Pavlenkin, N.A. Satykova, Filtrogenic gas hydrates in the Black Sea, Geol. Geofiz. 31 (1990) 10-19.

[12] A. Vassilev, L. Dimitrov, Spatial and quantity evaluation of the Black Sea gas hydrates, Geol. Geofiz. 43 (2002) 672-684.

[13] J. Peckmann, A. Reimer, U. Luth, C. Luth, B.T. Hansen, C. Heinicke, J. Hoefs, J. Reitner, Methane-derived carbonates and authigenic pyrite from the northwestern Black Sea, Mar. Geol. 177 (2001) 129-150.

[14] T. Lüdmann, H.K. Wong, P. Konerding, M. Zillmer, J. Petersen, E. Flüh, Heat flow and quantity of methane deduced from a gas hydrate field in the vicinity of the Dnieper Canyon, northwestern Black Sea, Geo Mar. Lett. 24 (2004) 182-193.

[15] K.A. Kvenvolden, T.D. Lorenson, The global occurrence of natural gas hydrates, in: C.K. Paull, W.P. Dillon (Eds.), Natural Gas Hydrates: Occurrence, Distribution, and Detection, American Geophysical Union, Washington, DC, 2001, pp. 3-18.

[16] E.D. Sloan, Clathrate Hydrates of Natural Gases, 2nd ed., Marcel Dekker, New York, NY, 1998, 705 pp.

[17] B.A. Buffett, Clathrate hydrates, Annu. Rev. Earth Planet. Sci. 28 (2000) 477-507.

[18] B.A. Buffett, O.Y. Zatsepina, Formation of gas hydrate from dissolved gas in natural porous media, Mar. Geol. 164 (2000) 69-77.

[19] G. Rehder, S.H. Kirby, W.B. Durham, L.A. Stern, E.T. Peltzer, J. Pinkston, P.G. Brewer, Dissolution rates of pure methane hydrate and carbon-dioxide hydrate in undersaturated seawater at 1000-m depth, Geochim. Cosmochim. Acta 68 (2004) 285-292.

[20] D.S. Kelley, J.A. Karson, G.L. Früh-Green, D.R. Yoerger, T.M. Shank, D.A. Butterfield, J.M. Hayes, M.O. Schrenk, E.J. Olson, G. Proskurowski, M. Jakuba, A. Bradley, B. Larson, K. Ludwig, D. Glickson, K. Buckman, A.S. Bradley, W.J. Brazelton, K. Roe, M.J. Elend, A. Delacour, S.M. Bernasconi, M.D. Lilley, J.A. Baross, R.E. Summons, S.P. Sylva, A serpentinite-hosted ecosystem: the lost city hydrothermal field, Science 307 (2005) $1428-1434$.

[21] D.L. Valentine, D.C. Blanton, W.S. Reeburgh, M. Kastner, Water column methane oxidation adjacent to an area of active hydrate dissociation, Eel River Basin, Geochim. Cosmochim. Acta 65 (2001) 2633-2640.

[22] L.D.D. Harvey, Z. Huang, Evaluation of the potential impact of methane clathrate destabilization on future global warming, J. Geophys. Res. 100 (1995) 2905-2926.

[23] M.E. Katz, D.K. Pak, G.R. Dickens, K.G. Miller, The source and fate of massive carbon input during the latest Paleocene thermal maximum, Science 286 (1999) 1531-1533.

[24] J.P. Kennett, K.G. Cannariato, I.L. Hendy, R.J. Behl, Methane Hydrates in Quaternary Climate Change: The Clathrate Gun Hypothesis, American Geophysical Union, Washington, DC, 2003, 216 pp.

[25] K.S. Grabowski, D.L. Knies, S.J. Tumey, J.W. Pohlman, C.S. Mitchell, R.B. Coffin, Carbon pool analysis of methane hydrate regions in the seafloor by accelerator mass spectrometry, Nucl. Instrum. Methods Phys. Res., B Beam Interact. Mater. Atoms 223-224 (2004) 435-440.

[26] G. Winckler, W. Aeschbach-Hertig, J. Holocher, R. Kipfer, I. Levin, C. Poss, G. Rehder, E. Suess, P. Schlosser, Noble gases and radiocarbon in natural gas hydrates, Geophys. Res. Lett. 29 (2002), doi:10.1029/2001GL014013.

[27] J.D. Kessler, Studies on Oceanic Methane: Concentrations, Stable Isotope Ratios, and Natural Radiocarbon Measurements, Ph.D., University of California Irvine, 2005.
[28] M.I. Scranton, Temporal variations in the methane content of the Cariaco Trench, Deep-Sea Res. 35 (1988) 1511-1523.

[29] T.M. Hoehler, M.J. Alperin, D.B. Albert, C.S. Martens, Field and laboratory studies of methane oxidation in an anoxic marine sediment: evidence for a methanogen-sulfate reducer consortium, Glob. Biogeochem. Cycles 8 (1994) 451-463.

[30] T.M. Hoehler, M.J. Alperin, D.B. Albert, C.S. Martens, Thermodynamic control on hydrogen concentrations in anoxic sediments, Geochim. Cosmochim. Acta 62 (1998) 1745-1756.

[31] D.B. Albert, C. Taylor, C.S. Martens, Sulfate reduction rates and low molecular weight fatty acid concentrations in the water column and surficial sediments of the Black Sea, Deep-Sea Res., Part 1, Oceanogr. Res. Pap. 42 (1995) 1239-1260.

[32] M.A. de Angelis, C. Lee, Methane production during zooplankton grazing on marine phytoplankton, Limnol. Oceanogr. 39 (1994) 1298-1308.

[33] D.G. Marty, Methanogenic bacteria in seawater, Limnol. Oceanogr. 38 (1993) 452-456.

[34] D.M. Karl, B.D. Tilbrook, Production and transport of methane in oceanic particulate organic matter, Nature 368 (1994) $732-734$.

[35] R.A. Burke Jr., D.F. Reid, J.M. Brooks, D.M. Lavoie, Upper water column methane geochemistry in the eastern tropical North Pacific, Limnol. Oceanogr. 28 (1983) 19-32.

[36] F.J. Cynar, A.A. Yayanos, The distribution of methane in the upper waters of the Southern California Bight, J. Geophys. Res. 97 (1992) 11269-11285.

[37] F.J. Cynar, A.A. Yayanos, The oceanic distribution of methane and its flux to the atmosphere over Southern California waters, in: R.S. Oremland (Ed.), Biogeochemistry of Global Change: Radiatively Active Trace Gases, Chapman and Hall, New York, NY, 1993, pp. 551-573.

[38] M.E. Holmes, F.J. Sansone, T.M. Rust, B.N. Popp, Methane production, consumption, and air-sea exchange in the open ocean: an evaluation based on carbon isotopic ratios, Glob. Biogeochem. Cycles 14 (2000) 1-10.

[39] F.J. Sansone, B.N. Popp, A. Gasc, A.W. Graham, T.M. Rust, Highly elevated methane in the eastern tropical North Pacific and associated isotopically enriched fluxes to the atmosphere, Geophys. Res. Lett. 28 (2001) 4567-4570.

[40] B.B. Ward, The subsurface methane maximum in the Southern California Bight, Cont. Shelf Res. 12 (1992) 735-752.

[41] B.B. Ward, K.A. Kilpatrick, Methane oxidation associated with mid-depth methane maxima in the Southern California Bight, Cont. Shelf Res. 13 (1993) 1111-1122.

[42] S. Watanabe, N. Higashitani, N. Tsurushima, S. Tsunogai, Methane in the Western North Pacific, J. Oceanogr. 51 (1995) 39-60.

[43] W.S. Reeburgh, Anaerobic methane oxidation: rate depth distributions in Skan Bay sediments, Earth Planet. Sci. Lett. 47 (1980) 345-352.

[44] S. Yamamoto, J.B. Alcauskas, T.E. Crozier, Solubility of methane in distilled water and seawater, J. Chem. Eng. Data 21 (1976) 78-80.

[45] W.S. Broecker, An application of natural radon to problems in ocean circulation, in: T. Ichiye (Ed.), Symposium on Diffusion in Oceans and Fresh Waters, Lamont Geological Observatory of Columbia University, Palisades, New York, 1965, pp. 116-145.

[46] G.G. Mathieu, P.E. Biscaye, R.A. Lupton, D.E. Hammond, System for measurement of ${ }^{222} \mathrm{Rn}$ at low levels in natural waters, Health Phys. 55 (1988) 989-992.

[47] M. Stuiver, H.A. Polach, Discussion: reporting ${ }^{14} \mathrm{C}$ data, Radiocarbon 19 (1977) 355-363. 
[48] J.D. Kessler, W.S. Reeburgh, Preparation of natural methane samples for stable isotope and radiocarbon analysis, Limnol. Oceanogr. : Methods 3 (2005) 408-418.

[49] J.D. Kessler, W.S. Reeburgh, S.C. Tyler, Controls on methane concentration and stable isotope $\left(\delta^{2} \mathrm{H}-\mathrm{CH}_{4}\right.$ and $\left.\delta^{13} \mathrm{C}-\mathrm{CH}_{4}\right)$ distributions in the water columns of the Black Sea and Cariaco Basin, Glob. Biogeochem. Cycles (submitted for publication).

[50] W.S. Reeburgh, S.C. Tyler, J. Carroll, Stable carbon and hydrogen isotope measurements on Black Sea water column methane, Deep-Sea Res. (submitted for publication).

[51] P.P. Tans, A note on isotopic ratios and the global atmospheric methane budget, Glob. Biogeochem. Cycles 11 (1997) 77-81.

[52] W.G. Deuser, Evolution of anoxic conditions in Black Sea during Holocene, in: E.T. Degens, D.A. Ross (Eds.), The Black SeaGeology, Chemistry, and Biology, The American Association of Petroleum Geologists, Tulsa, OK, 1974, pp. 133-136.

[53] A.G. Robinson, J.H. Rudat, C.J. Banks, R.L.F. Wiles, Petroleum geology of the Black Sea, Mar. Pet. Geol. 13 (1996) 195-223.

[54] J. Bigeleisen, M. Wolfsberg, Theoretical and experimental aspects of isotope effects in chemical kinetics, Adv. Chem. Phys. 1 (1958) 15-76.

[55] M.J. Alperin, W.S. Reeburgh, M.J. Whiticar, Carbon and hydrogen isotope fractionation resulting from anaerobic methane oxidation, Glob. Biogeochem. Cycles 2 (1988) 279-288.

[56] C.S. Martens, D.B. Albert, M.J. Alperin, Stable isotope tracing of anaerobic methane oxidation in gassy sediments of Eckernförde Bay, German Baltic Sea, Am. J. Sci. 299 (1999) 589-610.

[57] J.D. Kessler, W.S. Reeburgh, J. Southon, R. Varela, Fossil methane source dominates Cariaco Basin water column methane geochemistry, Geophys. Res. Lett. 32 (2005), doi:10.1029/ 2005 GL022984.

[58] M.J. Alperin, W.S. Reeburgh, Geochemical observations supporting anaerobic methane oxidation, in: R.L. Crawford, R.S. Hanson (Eds.), Microbial Growth on $\mathrm{C}_{1}$ Compounds, American Society for Microbiology, Washington, D.C., 1984, pp. 282-289.

[59] M.A. Arthur, W.E. Dean, E.D. Neff, B.J. Hay, J. King, G. Jones, Varve calibrated records of carbonate and organic carbon accumulation over the last 2000 years in the Black Sea, Glob. Biogeochem. Cycles 8 (1994) 195-217.

[60] G.A. Jones, A.R. Gagnon, Radiocarbon chronology of Black Sea sediments, Deep-Sea Res., Part 1, Oceanogr. Res. Pap. 41 (1994) $531-557$.

[61] B.B. Ward, K.A. Kilpatrick, P.C. Novelli, M.I. Scranton, Methane oxidation and methane fluxes in the ocean surface layer and deep anoxic waters, Nature 327 (1987) 226-229.

[62] G. Rehder, P.W. Brewer, E.T. Peltzer, G. Friederich, Enhanced lifetime of methane bubble streams within the deep ocean, Geophys. Res. Lett. 29 (2002), doi:10.1029/2001GL013966.

[63] W.S. Reeburgh, Global methane biogeochemistry, in: H.D. Holland, K.K. Turekian (Eds.), Treatise on Geochemistry, The Atmosphere, vol. 4, Elsevier-Pergamon, Oxford, 2003, pp. $65-89$.

[64] R.I. Kutas, S.I. Paliy, O.M. Rusakov, Deep faults, heat flow and gas leakage in the northern Black Sea, Geo Mar. Lett. 24 (2004) $163-168$. 